DOI: https://doi.org/10.24144/2409-6857.2019.1(53).154-162

УДК 658.14/.17

Давидов О.I.

\title{
МОДЕЛЬ ФОРМУВАННЯ ФУНДАМЕНТАЛЬНО-СТЕЙКХОЛДЕРСЬКОЇ ДОДАНОЇ ВАРТОСТІ ПІДПРИЕМСТВ
}

\begin{abstract}
У статті розроблено модель формування фундаментально-стейкхолдерської доданої вартості підприємств з позичій отримання фінансового результату їх діяльності і трансформачії інвестованого капіталу. Визначено економічний зміст і склад доходів і витрат у процесі створення фундаментальностейкхолдерської доданої вартості як фінансового результату діяльності підприємств. Обгрунтовано послідовність формування фундаментально-стейкхолдерської доданої вартості підприємств.

Ключові слова: фундаментально-стейкхолдерська додана вартість, модель, фінансовий результат, доходи, витрати, інвестований капітал, фінансові вигоди, підприємство, стейкхолдери.
\end{abstract}

Постановка проблеми. Вартісно-орієнтоване управління $є$ інноваційною концепцією управління на мікроекономічному рівні, реалізація якої націлена на збільшення вартості підприємств. В умовах багатомірності та видової різноманітності вартості головною метою вартісно-орієнтованого управління має бути максимізація фундаментально-стейкхолдерської доданої вартості, яка виступає грошовим еквівалентом цінності суб'єкта господарювання 3 позицій задоволення власних і стейкхолдерських інтересів.

Фундаментально-стейкхолдерська додана вартість $\epsilon$ інтегрованим фінансовим показником, що відображає кількісну оцінку додаткових фінансових вигод підприємства та його ключових стейкхолдерів.

Здійснення вартісно-орієнтованого управління за критерієм зростання фундаментальностейкхолдерської доданої вартості потребує розуміння логіки вартісно-утворюючих процесів на мікрорівні сучасної економіки, розробки моделі формування фундаментальностейкхолдерської доданої вартості підприємств.

Аналіз останніх досліджень і публікацій. Вагомий внесок у дослідження процесів формування вартості підприємства та їх моделювання зробили такі вчені, як Г. Арнольд [1], Д. Л. Волков [2], Р. І. Заворотній [3], І.В. Івашковська [4], Т. Коллер [5], М. Гоедхарт [5], Д. Весселс [5], О. В. Мілінчук [6], Ю. К. Плетньова [7], В. М. Марченко [7], В. М. Порохня [8],

() Давидов О. I., кандидат економічних наук, доцент, професор кафедри фінансів, банківської справи та страхування, Харківський національний університет імені В. Н. Каразіна, м. Харків, тел.: +380661910770, e-mail: a.dav@ukr.net
В. О.Лось [8], І. Таранов [9], Н. В. Шевчук [10]. Значна увага цими науковцями приділяється вивченню особливостей формування економічної доданої вартості (Economic Value Added - EVA), ринкової доданої вартості (Market Value Added MVA), рентабельності інвестицій за грошовими потоками (Cash Flow Return on Investment CFROI), грошової доданої вартості (Cash Value Added - CVA), акціонерної доданої вартості (Shareholder Value Added -SVA), доданої вартості для стейкхолдерів (Stakeholder Value Added STVA).

У вартісно-орієнтованому управлінні підприємствами фундаментально-стейкхолдерська додана вартість виступає новою керованою вартістю, на максимізацію якої повинні бути спрямовані зусилля менеджерів. Тому в наукових працях вищезазначених вчених не розглядається проблематика формування саме фундаментально-стейкхолдерської доданої вартості. На теперішній час науковцями не розроблена модель формування фундаментальностейкхолдерської доданої вартості, не вивчені питання формування цієї вартості у взаємозв'язку 3 отриманням фінансового результату діяльності підприємств i трансформацією інвестованого капіталу, не визначений склад і зміст доходів івитрат в процесі створення фундаментальностейкхолдерської доданої вартості як фінансового результату діяльності підприємств, не зроблено відповідної аргументації щодо послідовності формування даної вартості в сучасних економічних умовах.

Формулювання цілей статті. Метою статті $\epsilon$ розробка моделі формування фундаментальностейкхолдерської доданої вартості підприємств у процесі впровадження системи вартісноорієнтованого управління на мікрорівні сучасної економіки. 
Опис основного матеріалу дослідження. Вартісно-утворюючі процеси на мікрорівні сучасної економіки пов'язані 3 формуванням фінансового результату діяльності суб'єктів господарювання, який виступає їх найбільш повною ціннісною характеристикою. Фінансовий результат $€$ підсумком зіставлення певних доходів і витрат діяльності підприємства. У зв'язку з цим формування фундаментально-стейкхолдерської доданої вартості слід розглядати як процес отримання доходів і здійснення витрат у такій комбінації, що відображає досягнення фінансового результату у вигляді додаткових фінансових вигод підприємства та його ключових стейкхолдерів.

Формування холдерської доданої вартості $\epsilon$ складним, багатогранним процесом трансформації інвестованого капіталу в ході здійснення операційної та неопераційної діяльності підприємства в фундаментально-стейкхолдерську додану вартість. У цьому сенсі інвестований капітал виступає вихідним пунктом формування фундаментально-стейкхолдерської доданої вартості та генератором іï створення в сучасних економічних умовах.

Інвестований капітал формується за рахунок власного та позикового капіталів і становить сукупність фінансових ресурсів, що інвестуються у створення необоротних та оборотних активів підприємства 3 метою отримання доходів від операційної і неопераційної діяльності суб'єкта господарювання.

Процес формування фундаментальностейкхолдерської доданої вартості розглядається автором відносно виробничих промислових підприємств.

У результаті операційної діяльності підприємства формуються операційні доходи. До цих доходів згідно порядку складання фінансової звітності підприємств слід віднести такі доходи: чистий дохід від реалізації продукції (товарів, робіт, послуг); інші операційні доходи; дохід від зміни вартості активів, які оцінюються за справедливою вартістю.

Неопераційні доходи включають доходи, що не пов'язані 3 операційною діяльністю підприємства: дохід від участі в капіталі, інші фінансові доходи, інші доходи, дохід від благодійної допомоги.

У таблиці 1 представлена характеристика операційних i неопераційних доходів підприємства у відповідності 3 порядком розкриття інформації за статтями «Звіту про фінансові результати (Звіту про сукупний дохід)» (форма № 2).

Таблиця 1

\section{Характеристика операційних і неопераційних доходів підприсмства*}

\begin{tabular}{|c|c|c|}
\hline $\begin{array}{l}\text { Операційні та } \\
\text { неопераційні } \\
\text { доходи }\end{array}$ & $\begin{array}{c}\text { Код рядка у } \\
\text { «Звіті про } \\
\text { фінансові } \\
\text { результати } \\
\text { (Звіті про } \\
\text { сукупний } \\
\text { дохід)» (форма } \\
\text { № 2) }\end{array}$ & Характеристика \\
\hline $\begin{array}{l}\text { Чистий дохід від } \\
\text { реалізації } \\
\text { продукції } \\
\text { (товарів, робіт, } \\
\text { послуг) }\end{array}$ & 2000 & $\begin{array}{l}\text { Дохід (виручка) від реалізації продукції, товарів, робіт, послуг (у тому } \\
\text { числі платежі від оренди об’єктів інвестиційної нерухомості) за } \\
\text { вирахуванням наданих знижок, вартості повернутих раніше проданих } \\
\text { товарів, доходів, що за договорами належать комітентам } \\
\text { (принципалам тощо), та податків і зборів. }\end{array}$ \\
\hline $\begin{array}{c}\text { Інші операційні } \\
\text { доходи }\end{array}$ & 2120 & $\begin{array}{l}\text { Суми інших доходів від операційної діяльності підприємства, крім } \\
\text { чистого доходу від реалізації продукції (товарів, робіт, послуг): дохід } \\
\text { від операційної оренди активів; дохід від операційних курсових } \\
\text { різниць; відшкодування раніше списаних активів; дохід від роялті, } \\
\text { відсотків, отриманих на залишки коштів на поточних рахунках в } \\
\text { банках, дохід від реалізації оборотних активів (крім фінансових } \\
\text { інвестицій), необоротних активів, утримуваних для продажу, та групи } \\
\text { вибутя, дохід від списання кредиторської заборгованості, одержані } \\
\text { штрафи, пені, неустойки тощо. }\end{array}$ \\
\hline $\begin{array}{c}\text { Дохід від зміни } \\
\text { вартості активів, } \\
\text { які оцінюються за } \\
\text { справедливою } \\
\text { вартістю } \\
\text { (додаткова стаття) }\end{array}$ & 2121 & $\begin{array}{l}\text { Дохід від зміни вартості всіх активів (фінансових інструментів, } \\
\text { інвестиційної нерухомості та інших), які оцінюються за справедливою } \\
\text { вартістю. }\end{array}$ \\
\hline
\end{tabular}


продовження таблиці 1

\begin{tabular}{|c|c|c|}
\hline $\begin{array}{l}\text { Операційні та } \\
\text { неопераційні } \\
\text { доходи }\end{array}$ & $\begin{array}{c}\text { Код рядка у } \\
\text { «Звіті про } \\
\text { фінансові } \\
\text { результати } \\
\text { (Звіті про } \\
\text { сукупний } \\
\text { дохід)» (форма } \\
\text { № 2) }\end{array}$ & Характеристика \\
\hline $\begin{array}{l}\text { Дохід від участі в } \\
\text { капіталі }\end{array}$ & 2200 & $\begin{array}{l}\text { Дохід, отриманий від інвестицій в асоційовані, дочірні або спільні } \\
\text { підприємства, облік яких ведеться методом участі в капіталі. }\end{array}$ \\
\hline $\begin{array}{c}\text { Інші фінансові } \\
\text { доходи }\end{array}$ & 2220 & $\begin{array}{l}\text { Дивіденди, відсотки та інші доходи, отримані від фінансових } \\
\text { інвестицій (крім доходів, які обліковуються за методом участі в } \\
\text { капіталі). }\end{array}$ \\
\hline Інші доходи & 2240 & $\begin{array}{l}\text { Дохід від реалізації фінансових інвестицій; дохід від неопераційних } \\
\text { курсових різниць; дохід підприємств (крім тих, основною діяльністю } \\
\text { яких є торгівля цінними паперами) від зміни балансової вартості } \\
\text { фінансових інструментів, які оцінюються за справедливою вартістю, } \\
\text { та інші доходи, які виникають у процесі господарської діяльності, але } \\
\text { не пов’язані з операційною діяльністю підприємства. }\end{array}$ \\
\hline $\begin{array}{c}\text { Дохід від } \\
\text { благодійної } \\
\text { допомоги } \\
\text { (додаткова стаття) }\end{array}$ & 2241 & $\begin{array}{l}\text { Дохід, пов’язаний з благодійною допомогою, яка відповідно до } \\
\text { законодавства звільняється від оподаткування податком на додану } \\
\text { вартість, що визнається у порядку, встановленому Положенням } \\
\text { (стандартом) бухгалтерського обліку } 15 \text { «дохід». }\end{array}$ \\
\hline
\end{tabular}

*Складено автором на основі [11; 12]

У випадку подання підприємством консолідованої фінансової звітності розрахунок операційних і неопераційних доходів здійснюється за даними «Консолідованого звіту про фінансові результати (Звіту про сукупний дохід)» (форма № 2-к). Відповідні статті цього звіту мають такі ж коди рядків, як і у «Звіті про фінансові результати (Звіті про сукупний дохід)» (форма № 2).

У сукупності операційні та неопераційні доходи забезпечують формування загального доходу, за рахунок якого покриваються відповідні витрати у процесі створення фундаментальностейкхолдерської доданої вартості.

Явні витрати, що відображаються у фінансовій звітності підприємств (експліцитні витрати), порізному приймають участь у формуванні фінансових вигод підприємства та його ключових

стейкхолдерів дерської вартості).

Серед таких витрат необхідно виділити, передусім, групу нестратегічних експліцитних витрат. У цій групі об'єднуються витрати, які безпосередньо не формуюють фінансових вигод підприємства та його основних стейкхолдерів, але виконують підтримуючу функцію у процесі створення фундаментально-стейкхолдерської вартості. У групу нестратегічних експліцитних витрат потрібно включити наступні витрати, що відображаються у фінансовій звітності підприємств: матеріальні затрати, амортизація, інші операційні витрати, втрати від участі в капіталі, інші витрати.

Характеристика нестратегічних експліцитних витрат підприємства наведена у таблиці 2.

Таблиця 2

Характеристика нестратегічних експліщитних витрат підприємства*

\begin{tabular}{|c|c|c|}
\hline $\begin{array}{c}\text { Нестратегічні } \\
\text { експліцитні витрати }\end{array}$ & $\begin{array}{c}\text { Код рядка у } \\
\text { «Звіті про } \\
\text { фінансові } \\
\text { результати } \\
\text { (Звіті про } \\
\text { сукупний } \\
\text { дохід)» } \\
\text { (форма № 2) }\end{array}$ & Характеристика \\
\hline Матеріальні затрати & 2500 & $\begin{array}{l}\text { Вартість витрачених у виробництві (крім продукту власного } \\
\text { виробництва): сировини й основних матеріалів; купівельних } \\
\text { напівфабрикатів та комплектуючих виробів; палива й енергії; } \\
\text { будівельних матеріалів; запасних частин; тари й тарних матеріалів; } \\
\text { допоміжних та інших матеріалів. }\end{array}$ \\
\hline
\end{tabular}


продовження таблиці 2

\begin{tabular}{|c|c|c|}
\hline $\begin{array}{c}\text { Нестратегічні } \\
\text { експліцитні витрати }\end{array}$ & $\begin{array}{l}\text { Код рядка у } \\
\text { «Звіті про } \\
\text { фінансові } \\
\text { результати } \\
\text { (Звіті про } \\
\text { сукупний } \\
\text { дохід)» } \\
\text { (форма № 2) }\end{array}$ & Характеристика \\
\hline Амортизація & 2515 & $\begin{array}{l}\text { Сума нарахованої амортизації основних засобів, нематеріальних } \\
\text { активів та інших необоротних матеріальних активів. }\end{array}$ \\
\hline $\begin{array}{c}\text { Інші операційні } \\
\text { витрати }\end{array}$ & 2520 & $\begin{array}{l}\text { Витрати операційної діяльності, які не увійшли до складу наступних } \\
\text { елементів: матеріальні затрати, витрати на оплату праці, } \\
\text { відрахування на соціальні заходи, амортизація (зокрема витрати на } \\
\text { відрядження, на послуги зв'язку, плата за розрахунково-касове } \\
\text { обслуговування тощо). }\end{array}$ \\
\hline $\begin{array}{l}\text { Втрати від участі в } \\
\text { капіталі }\end{array}$ & 2255 & $\begin{array}{l}\text { Збиток від інвестицій в асоційовані, дочірні або спільні } \\
\text { підприємства, облік яких ведеться методом участі в капіталі. }\end{array}$ \\
\hline Інші витрати & 2270 & $\begin{array}{l}\text { Собівартість реалізації фінансових інвестицій; втрати від } \\
\text { неопераційних курсових різниць; втрати від уцінки фінансових } \\
\text { інвестицій та необоротних активів; витрати підприємств (крім тих, } \\
\text { основною діяльністю яких є торгівля цінними паперами) від зміни } \\
\text { балансової вартості фінансових інструментів, які оцінюються за } \\
\text { справедливою вартістю; інші витрати, які виникають у процесі } \\
\text { господарської діяльності (крім фінансових витрат), але не пов'язані } \\
\text { з операційною діяльністю підприємства. }\end{array}$ \\
\hline
\end{tabular}

*Складено автором на основі $[11 ; 12 ; 13]$

y випадку подання підприємством консолідованої фінансової звітності нестратегічні експліцитні витрати визначаються за даними «Консолідованого звіту про фінансові результати (Звіту про сукупний дохід)» (форма № 2-к). Відповідні статті цього звіту мають такі ж коди рядків, як і у «Звіті про фінансові результати (Звіті про сукупний дохід)» (форма № 2).

У складі експліцитних витрат, окрім нестратегічних, слід виділити також стратегічні витрати. Здійснення стратегічних експліцитних витрат забезпечує створення фінансових вигод підприємства та його ключових стейкхолдерів і на цій основі формування фундаментальностейкхолдерської вартості. До такої групи витрат доцільно віднести наступні витрати, що відображаються у фінансовій звітності підприємств: витрати на оплату праці, відрахування на соціальні заходи, фінансові витрати, витрати з податку на прибуток.

У таблиці 3 наведена характеристика стратегічних експліцитних витрат підприємства.

Таблиця 3

\section{Характеристика стратегічних експліцитних витрат підприємства}

\begin{tabular}{|c|c|c|}
\hline $\begin{array}{l}\text { Стратегічні } \\
\text { експліцитні } \\
\text { витрати }\end{array}$ & $\begin{array}{c}\text { Код рядка у «Звіті про } \\
\text { фінансові результати } \\
\text { (Звіті про сукупний } \\
\text { дохід)» (форма № 2) } \\
\end{array}$ & Характеристика \\
\hline $\begin{array}{c}\text { Витрати на оплату } \\
\text { праці }\end{array}$ & 2505 & $\begin{array}{l}\text { Заробітна плата за окладами й тарифами, премії та заохочення, } \\
\text { матеріальна допомога, компенсаційні виплати, оплата відпусток } \\
\text { та іншого невідпрацьованого часу, інші витрати на оплату праці. }\end{array}$ \\
\hline $\begin{array}{l}\text { Відрахування на } \\
\text { соціальні заходи }\end{array}$ & 2510 & $\begin{array}{l}\text { Відрахування на загальнообов'язкове державне соціальне } \\
\text { страхування, відрахування на індивідуальне страхування } \\
\text { персоналу підприємства, відрахування на інші соціальні заходи. }\end{array}$ \\
\hline Фінансові витрати & 2250 & $\begin{array}{l}\text { Витрати на проценти та інші витрати підприємства, пов’язані із } \\
\text { запозиченнями (крім фінансових витрат, які включаються до } \\
\text { собівартості кваліфікаційних активів відповідно до Положення } \\
\text { (стандарту) бухгалтерського обліку } 31 \text { «Фінансові витрати»). }\end{array}$ \\
\hline $\begin{array}{c}\text { Витрати з податку } \\
\text { на прибуток }\end{array}$ & 2300 & $\begin{array}{l}\text { Сума витрат з податку на прибуток, визначена згідно } 3 \\
\text { Положенням (стандартом) бухгалтерського обліку } 17 \text { «Податок } \\
\text { на прибуток». }\end{array}$ \\
\hline
\end{tabular}

*Складено автором на основі [11; 12; 13] 
У випадку подання підприємством консолідованої фінансової звітності стратегічні експліцитні витрати визначаються за даними «Консолідованого звіту про фінансові результати (Звіту про сукупний дохід)» (форма № 2-к). Відповідні статті цього звіту мають такі ж коди рядків, як і у «Звіті про фінансові результати (Звіті про сукупний дохід)» (форма № 2).

Кожний компонент стратегічних експліцитних витрат виконує функцію щодо формування певних фінансових вигод підприємства та його ключових стейкхолдерів.

Оплата праці є еквівалентом вартості живої праці, яка у поєднанні із засобами виробництва, створює вартість продукту в процесі діяльності підприємств. Витрати на оплату праці характеризують вартість ринкового товару робочої сили, особливістю якої $€$ здатність створювати в процесі свого споживання нову вартість у розмірі, що перевищує вартість самої робочої сили.

Витрати на оплату праці мають забезпечувати об'єктивно-необхідний рівень відтворення робочої сили в існуючих соціально-економічних умовах шляхом виплати грошової винагороди персоналу підприємств у залежності від результатів його праці. Оплату праці наймані працівники отримують в результаті реалізації їх здатності до праці. Рівень оплати праці повинен бути достатнім для відновлення працездатності робітників, забезпечення розвитку їх фізичних i духовних сил. Від величини витрат на оплату праці залежить рівень життя та добробут працівників підприємства.

Витрати на оплату праці мають важливе значення також для забезпечення матеріальної мотивації працівників до досягнення високих кінцевих результатів праці в різних сферах фінансово-господарської підприємства, активізації функціонування людського капіталу.

Як справедливо відмічає М. В. Грідчіна, 3 урахуванням особливостей функціонування великих корпорацій в епоху інформаційного суспільства, інтелектуалізації та інноваційної спрямованості виробничо-господарської діяльності важливо адекватно оцінювати результати діяльності суб'єктів господарювання, трудові колективи яких є не просто найманим персоналом, який можна міняти хоч кожен день (без помітних втрат ефективності), а інтелектуальним капіталом підприємства, втрата якого не менш руйнівна, ніж втрата фінансового капіталу [14, с. 127].

Таким чином, цільове призначення витрат на оплату праці обумовлює їx стратегічну спрямованість на формування фінансових вигод персоналу як однієї 3 ключових груп стейкхолдерів підприємства.

За допомогою відрахувань на соціальні заходи забезпечується побудова системи загальнообов'язкового державного соціального страхування, яка орієнтована на соціальний захист громадян i передбачає організацію їx матеріального забезпечення у разі настання певних страхових випадків (хвороба, втрата працездатності, безробіття, старість тощо). Такий підхід дозволяє зберегти у даних випадках необхідні стандарти рівня та якості життя працівників та їхніх сімей.

Відрахування на соціальні заходи забезпечують формування фінансових вигод держави як важливого стейкхолдера підприємства, що обумовлює включення цих відрахувань у склад стратегічних експліцитних витрат.

Фінансові витрати пов'язані 3 обслуговуванням позикового капіталу і $є$ ціною, яку платить підприємство за залучення фінансових ресурсів для здійснення фінансовогосподарської діяльності та іiі розвитку. Ця ціна включає витрати у формі відсотків за отриманими кредитами та позиками, випущеними облігаціями, фінансовою орендою та інші витрати підприємства за запозиченнями.

У результаті здійснення підприємством фінансових витрат його стейкхолдери кредитори отримують відповідні фінансові вигоди, що дає підставу для віднесення даних витрат до стратегічних експліцитних витрат.

Витрати 3 податку на прибуток забезпечують надходження коштів державі у процесі оподаткування прибутку підприємства, тобто ці витрати безпосередньо формують фінансові вигоди такого стейкхолдера як держава і тому носять стратегічний характер 3 точки зору створення фундаментально-стейкхолдерської вартості суб' єкта господарювання.

Окрім стратегічних експліцитних витрат 3 формуванням фінансових вигод підприємства та його ключових стейкхолдерів пов'язано отримання чистого прибутку. Чистий прибуток слід вважати фінансовою вигодою для самого підприємства, оскільки за рахунок цього прибутку фінансується його виробничий i соціальний розвиток, здійснюється матеріальне стимулювання працівників, створюється резервний капітал. Крім того, у показнику чистого прибутку виражаються фінансові вигоди стейкхолдерів - власників підприємства, що обумовлене формуванням їх доходів через прямі виплати з чистого прибутку у вигляді дивідендів 
або в інших формах, а також можливістю зростання капіталу власників в процесі підвищення ринкової вартості (ринкової капіталізації) підприємства у результаті зміни пропорцій розподілу чистого прибутку на користь його пріоритетного спрямування на виробничий розвиток суб'єкта господарювання.

Фундаментально-стейкхолдерська вартість виражає інтегровану оцінку фінансових вигод підприємства та його ключових стейкхолдерів. Для створення вищезазначених фінансових вигод i, відповідно, фундаментально-стейкхолдерської вартості підприємство у результаті своєї діяльності має отримувати загальний дохід у розмірі, що перевищує величину нестратегічних експліцитних витрат. Розмір цього перевищення визначає величину фундаментальностейкхолдерського доходу як поточного фінансового результату, отримання якого забезпечує формування фінансових вигод підприємства та його головних стейкхолдерів шляхом подальшого розподілу даного доходу через механізм здійснення стратегічних експліцитних витрат i створення чистого прибутку.

У процесі формування фундаментальностейкхолдерської доданої вартості мають враховуватися не тільки нестратегічні експліцитні витрати, але й імпліцитні витрати (неявні витрати, що не відображаються у фінансовій звітності підприємств). Імпліцитні витрати - це ринкові витрати на інвестований у підприємство капітал з урахуванням наявних на ринку інвестиційних варіантів при незмінному рівні ризику вкладення коштів.

Формування інвестованого капіталу у вигляді власного та позикового капіталів здійснюється підприємством на платній основі. Платою за інвестований капітал виступає його ринкова вартість, яка характеризує відносний рівень ринково необхідних витрат на інвестований капітал. Ринкова вартість інвестованого капіталу відображає альтернативну вартість у вигляді фундаментально-стейкхолдерської дохідності інвестованого капіталу, яку має забезпечити підприємство 3 урахуванням наявних на ринку альтернативних можливостей інвестування 3 еквівалентним ризиком. При цьому під фундаментально-стейкхолдерською дохідністю інвестованого капіталу розуміється відношення фундаментально-стейкхолдерського доходу до величини інвестованого капіталу, що використовується для отримання даного доходу. Ринкова вартість інвестованого капіталу визначається середньогалузевим значенням фундаментально-стейкхолдерської

дохідності інвестованого капіталу.

Ринкові витрати на інвестований капітал - це абсолютний показник, який розраховується шляхом множення ринкової вартості інвестованого капіталу на величину інвестованого капіталу.

Фундаментально-стейкхолдерська додана вартість формується в результаті перевищення фундаментально-стейкхолдерського доходу над ринковими витратами на інвестований капітал. Розмір цього перевищення визначає величину додавання підприємством фундаментальностейкхолдерського доходу (фундаментальностейкхолдерської вартості) до ринкових витрат на інвестований капітал, тобто величину додаткових фінансових вигод підприємства та його ключових стейкхолдерів. Сформована таким чином фундаментально-стейкхолдерська додана вартість відображає стратегічний фінансовий результат, отримання якого забезпечує довгостроковий розвиток суб'єкта господарювання за рахунок найбільш повного задоволення фінансових інтересів підприємства та його головних стейкхолдерів.

У результаті проведених досліджень автором пропонується наступна модель формування фундаментально-стейкхолдерської доданої вартості підприємств (рис. 1).

Запропонована модель може бути використана для розробки ефективної методики оцінки фундаментально-стейкхолдерської доданої вартості, виявлення факторів іiі формування, побудови системи управління розвитком підприємств за траєкторією зростання фундаментально-стейкхолдерської доданої вартості.

Висновки i перспективи подальших досліджень. Формування фундаментальностейкхолдерської доданої вартості $\epsilon$ процесом отримання фінансового результату діяльності суб'єкта господарювання на основі зіставлення доходів i витрат, підсумок якого виступає кількісним виміром додаткових фінансових вигод підприємства та його ключових стейкхолдерів.

У процесі інвестування капіталу в підприємство та здійснення операційної та неопераційної діяльності суб'єкта господарювання формується загальний дохід, за рахунок якого мають покриватися нестратегічні експліцитні витрати для створення фундаментально-стейкхолдерської доданої вартості. У підсумку суб'єкт господарювання отримує поточний фінансовий результат фундаментально-стейкхолдерський дохід, подальший розподіл якого шляхом здійснення 


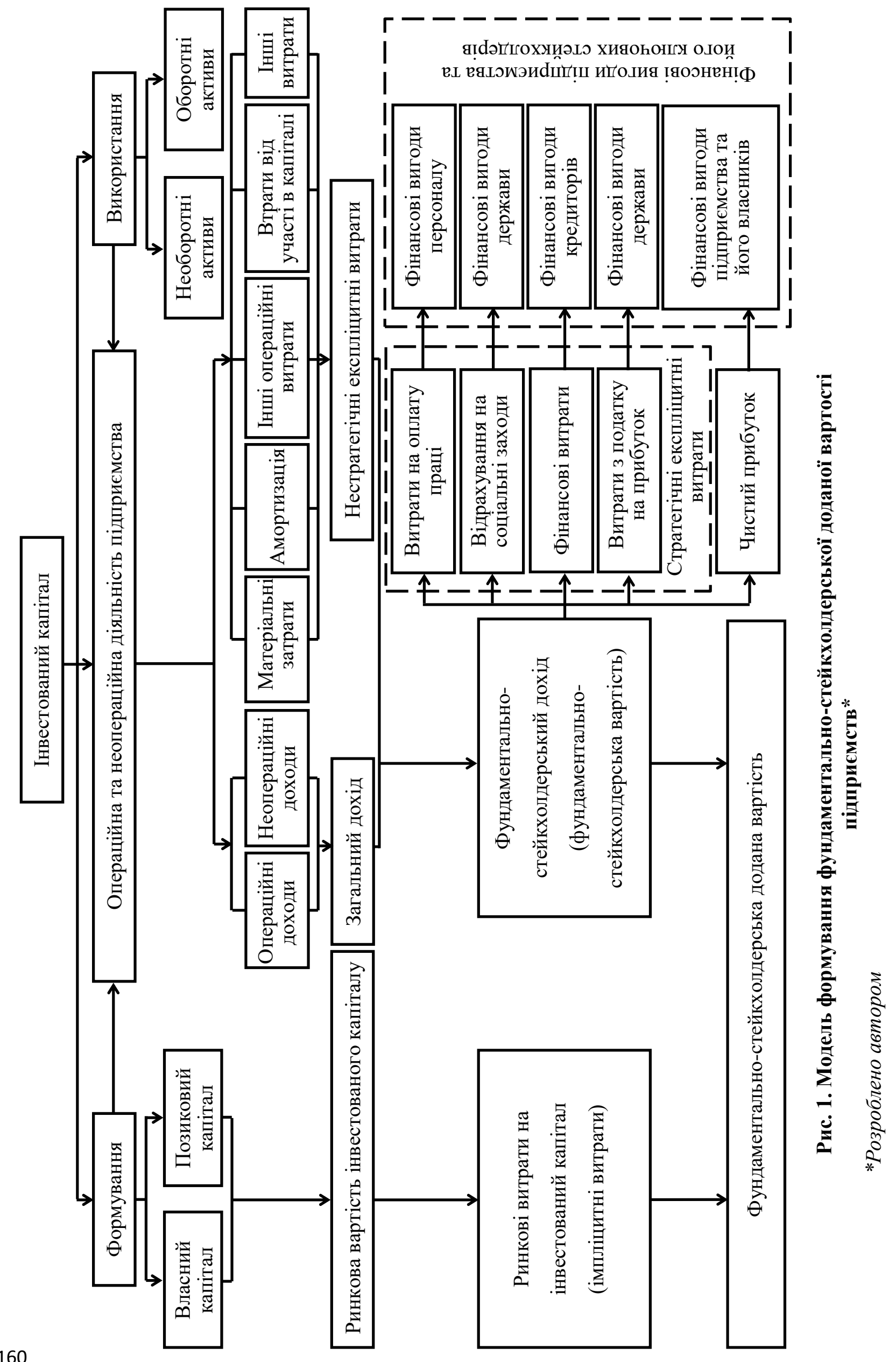


стратегічних експліцитних витрат і створення чистого прибутку забезпечує формування фундаментально-стейкхолдерської вартості у вигляді фінансових вигод підприємства та його основних стейкхолдерів.

Згідно запропонованої моделі фундаментально-стейкхолдерська додана вартість підприємств формується в результаті перевищення фундаментально-стейкхолдерського доходу над ринковими витратами на інвестований капітал. Розмір цього перевищення характеризує стратегічний фінансовий результат діяльності суб’єкта господарювання у формі додаткових фінансових вигод підприємства та його ключових стейкхолдерів.

Подальші дослідження пов'язані з розробкою ефективної методики визначення фундаментально-стейкхолдерської доданої вартості, ідентифікацією факторів їі формування, побудовою системи управління підприємствами за критерієм зростання фундаментальностейкхолдерської доданої вартості.

\section{СПИСОК ВИКОРИСТАНИХ ДЖЕРЕЛ}

1. Arnold G. The Handbook of Corporate Finance. A Business Companion to Financial Markets, Decisions and Techniques. / G. Arnold. - Pearson Education. - Financial Times Prentice Hall, 2005. - 716 p.

2. Волков Д. Л. Теория ценностно-ориентированного менеджмента: финансовый и бухгалтерский аспекты / Д.

Л. Волков. - СПб.: Изд-во «Высшая школа менеджмента»; Издат. дом С.-Петерб. гос. ун-та, 2008. - 320 с.

3. Заворотній Р. І. Фінансова оцінка бізнесу: теорія, практика та інноваційні підходи: монографія / P. I. Заворотній. - К.: КНЕУ, 2012. - 295 с.

4. Ивашковская И. В. Моделирование стоимости компании. Стратегическая ответственность совета директоров / И. В. Ивашковская. - М.: ИНФРА-М, 2013. - 430 с.

5. Koller T. Valuation: Measuring and Managing the Value of Companies / T. Koller, M. Goedhart, D. Wessels. - Fifth edition. - New Jersey: John Wiley \& Sons, Inc., 2010. - 862 p.

6. Мілінчук О. В. Ефективність вартісно-орієнтованого управління: ключові показники / О. В. Мілінчук // Вісник Житомирського державного технологічного університету. Серія: Економічні науки. - 2016. - № 1. - С. 86-96.

7. Плетньова Ю. К. Аналіз існуючих методик розрахунку доданої вартості на підприємстві / Ю. К. Плетньова, В. М. Марченко // Економічний аналіз. - 2018. - Т. 28. - № 2. - С. 168-175.

8. Порохня В. М. Моделювання економічної доданої вартості на підприємстві / В. М. Порохня, В. О. Лось // Вісник Запорізького національного університету. Економічні науки . - 2008. - № 1. - С. $107-114$.

9. Таранов I. Оцінювання ефективності діяльності компанії в системі вартісноорієнтованого управління / I. Таранов // Галицький економічний вісник. - 2012. - № 3. - С. 47-60.

10. Шевчук Н. В. Сучасні моделі оцінювання доданої вартості підприємства / Н. В. Шевчук // Стратегія економічного розвитку України. - 2014. - № 35. - С. 271-277.

11. Національне положення (стандарт) бухгалтерського обліку 1 «Загальні вимоги до фінансової звітності»: затверджено наказом Міністерства фінансів України № 73 від 07.02.2013 р. [Електронний ресурс]. - Режим доступу: http://zakon.rada.gov.ua/laws/show/z0336-13

12. Методичні рекомендації щодо заповнення форм фінансової звітності : затверджено наказом Міністерства фінансів України № 433 від 28.03.2013 p. [Електронний ресурс]. - Режим доступу: http://zakon.rada.gov.ua/rada/show/v0433201-13/conv

13. Положення (стандарт) бухгалтерського обліку 16 «Витрати» : затверджено наказом Міністерства фінансів України № 318 від 31.12.1999 p. [Електронний ресурс]. - Режим доступу: https://zakon.rada.gov.ua/laws/show/z0027-00

14. Грідчіна М. В. Про додану вартість як показник результатів діяльності сучасних корпорацій / М. В. Грідчіна // Наукові праці МАУП. - 2013. - Вип. 1 (36). - С. 126-129.

\section{REFERENCES}

1. Arnold, G. (2005). The handbook of corporate finance. A business companion to financial markets, decisions and techniques, pearson education. Financial Times Prentice Hall [in English].

2. Volkov, D.L. (2008). Teoriya tsennostno-orientirovannogo menedzhmenta: finansovyy i bukhgalterskiy aspekty [Theory of value-based management: financial and accounting aspects]. Vysshaya shkola menedzhmenta, SanktPeterburg [in Russian].

3. Zavorotnii, R.I. (2012). Finansova otsinka biznesu: teoriia, praktyka ta innovatsiini pidkhody: monohrafiia [Financial evaluation of business: theory, practice and innovative approaches: monograph], KNEU, Kyiv [in Ukrainian].

4. Ivashkovskaya, I.V. (2013). Modelirovanie stoimosti kompanii. Strategicheskaya otvetstvennost soveta direktorov [Modelling the company value. Strategic responsibility of the board of directors]. INFRA-M, Moskva [in Russian].

5. Koller, T., \& Goedhart, M., \& Wessels, D. (2010). Valuation: measuring and managing the value of companies. John Wiley \& Sons, Inc., New Jersey [in English]. 
6. Milinchuk, O.V. (2016). Efektyvnist vartisno-oriientovanoho upravlinnia: kliuchovi pokaznyky [Efficiency of valuebased management: the key indicators], Visnyk Zhytomyrskoho derzhavnoho tekhnolohichnoho universytetu. Seriia: Ekonomichni nauky - Bulletin of the Zhytomyr State Technological University. Series: Economic Sciences, 1 (75), 86+96 [in Ukrainian].

7. Pletn'ova Yu.K. (2018). Analiz isnuyuchykh metodyk rozrakhunku dodanoyi vartosti na pidpryyemstvi [An analysis of existing methods of calculation of value added at an enterprise]. Ekonomichnyy analiz - Economic analysis, 2, 168175 [in Ukrainian].

8. Porokhnya, V.M. (2008). Modelyuvannya ekonomichnoyi dodanoyi vartosti na pidpryyemstvi [Modeling of economic added value at an enterprise]. Visnyk Zaporiz'koho natsional'noho universytetu. Ekonomichni nauky - Bulletin of the Zaporizhzhya National University. Economic Sciences, 1, 107-114 [in Ukrainian].

9. Taranov, I. (2012). Otsiniuvannia efektyvnosti diialnosti kompanii v systemi vartisnooriientovanoho upravlinnia [Evaluating the effectiveness of a company in the system of value-based management]. Galytskii ekonomichnyi visnyk Galician Economic Herald, 3, 47-60 [in Ukrainian].

10. Shevchuk, N.V. (2014). Suchasni modeli otsiniuvannia dodanoi vartosti pidpryiemstva [Modern models of enterprise value added estimation]. Stratehiia ekonomichnoho rozvytku Ukrainy - Strategy of economic development of Ukraine, 35, 271-277 [in Ukrainian].

11. Natsional'ne polozhennya (standart) bukhhalters'koho obliku 1 «Zahal'ni vymohy do finansovoyi zvitnosti»: zatverdzheno nakazom Ministerstva finansiv Ukrayiny № 73 vid 07.02.2013 r. [National Accounting Standard 1 «General requirements for financial statements»] (2013, February 07). zakon.rada.gov.ua. Retrieved from: http://zakon.rada.gov.ua/laws/show/z0336-13 [in Ukrainian].

12. Metodychni rekomendatsiyi shchodo zapovnennya form finansovoyi zvitnosti: zatverdzheno nakazom Ministerstva finansiv Ukrayiny № 433 vid 28.03.2013 r. [Methodical recommendations for completing the forms of financial reporting] (2013, March 28). zakon.rada.gov.ua. Retrieved from: http://zakon.rada.gov.ua/rada/show/v0433201-13/conv [in Ukrainian].

13. Polozhennya (standart) bukhhalters'koho obliku 16 «Vytraty»: zatverdzheno nakazom Ministerstva finansiv Ukrayiny № 318 vid 31.12.1999 r. [Regulation (standard) of accounting 16 «Expenses»] (1999, December 31). zakon.rada.gov.ua. Retrieved from: https://zakon.rada.gov.ua/laws/show/z0027-00 [in Ukrainian].

14. Hridchina, M.V. (2013). Pro dodanu vartist' yak pokaznyk rezul'tativ diyal'nosti suchasnykh korporatsiy [On value added as an indicator of performance of modern corporations]. Naukovi pratsi MAUP - Scientific works of MAUP, 1 (36), 126-129 [in Ukrainian].

Одержано 15.03.2019p. 